\title{
Artificial Intelligence by Artificial Neural Networks to Simulate Oat (Avena sativa L.) Grain Yield Through the Growing Cycle
}

\author{
Osmar Bruneslau Scremin
}

Exact Sciences and Engineering Department, Regional University of the Northwest of Rio Grande do Sul, Street of Comércio 3000, Universitário, Ijuí/RS - Brazil

ORCID: 0000-0003-0752-378X

E-mail: osmarscremin@hotmail.com

\section{José Antonio Gonzalez da Silva}

Agrarian Studies Department, Regional University of the Northwest of Rio Grande do Sul, Street of Comércio 3000, Universitário, Ijuí/RS - Brazil

ORCID: 0000-0002-9335-2421

E-mail: jagsfaem@yahoo.com.br

\section{Ivan Ricardo Carvalho}

Agrarian Studies Department, Regional University of the Northwest of Rio Grande do Sul, Street of Comércio 3000, Universitário, Ijuí/RS - Brazil

$$
\begin{aligned}
& \text { ORCID: 0000-0001-7947-4900 } \\
& \text { E-mail: carvalho.irc@gmail.com }
\end{aligned}
$$

\begin{abstract}
Ângela Teresinha Woschinski De Mamann (Corresponding author)
Federal Institute of Education, Science and Technology of Rio Grande do Sul, Street Nelsi Ribas Fritsch, 1111, Neighborhood Esperança, Ibirubá/RS - Brazil
\end{abstract}

ORCID: 0000-0002-3650-9007

E-mail: angela.mamann@ibiruba.ifrs.edu.br

Adriana Roselia Kraisig 
Exact Sciences and Engineering Department, Regional University of the Northwest of Rio Grande do Sul, Street of Comércio 3000, Universitário, Ijuí/RS - Brazil

ORCID: 0000-0002-5495-7700

E-mail: maryshelei@yahoo.com.br

Juliana Aozane da Rosa

Exact Sciences and Engineering Department, Regional University of the Northwest of Rio Grande do Sul, Street of Comércio 3000, Universitário, Ijuí/RS - Brazil

ORCID: 0000-0002-0430-1615

E-mail: juaozane@gmail.com

\section{Cibele Luisa Peter}

Exact Sciences and Engineering Department, Regional University of the Northwest of Rio Grande do Sul, Street of Comércio 3000, Universitário, Ijuí/RS - Brazil

ORCID:0000-0003-3376-8211

E-mail: cibele.peter2017@gmail.com

\section{Eduarda Warmbier}

Exact Sciences and Engineering Department, Regional University of the Northwest of Rio Grande do Sul, Street of Comércio 3000, Universitário, Ijuí/RS - Brazil

ORCID: 0000-0002-0526-1723

E-mail: eduarda.warmbier@gmail.com

\section{Laura Mensch Pereira}

Agrarian Studies Department, Regional University of the Northwest of Rio Grande do Sul, Street of Comércio 3000, Universitário, Ijuí/RS - Brazil

ORCID: 0000-0002-8073-069X

E-mail: lauramensch@gmail.com

\section{Natiane Carolina Ferrari Basso}

Agrarian Studies Department, Regional University of the Northwest of Rio Grande do Sul, 
Street of Comércio 3000, Universitário, Ijuí/RS - Brazil

ORCID: 0000-0002-6538-7299

E-mail: natianeferrari@gmail.com

\title{
Cláudia Vanessa Argenta
}

Agrarian Studies Department, Regional University of the Northwest of Rio Grande do Sul, Street of Comércio 3000, Universitário, Ijuí/RS - Brazil

ORCID: 0000-0003-4462-3384

E-mail: claudia_argenta@yahoo.com

\section{Ester Mafalda Matter}

Agrarian Studies Department, Regional University of the Northwest of Rio Grande do Sul, Street of Comércio 3000, Universitário, Ijuí/RS - Brazil

ORCID: 0000-0002-3433-3220

E-mail: estermafaldamatter@gmail.com

Received: Sep. 20, 2020

doi:10.5296/jas.v8i4.17711
Accepted: Oct. 15, $2020 \quad$ Published: Oct. 22, 2020

URL: https://doi.org/10.5296/jas.v8i4.17711

\begin{abstract}
Artificial neural networks simulating oat grain yield throughout the crop cycle, can represent an innovative proposal regarding management and decision making, reducing costs and maximizing profits. The objective of the study is to develop biomathematical models via artificial neural networks, capable of predicting the productivity of oat grains by meteorological variables, nitrogen management and biomass obtained throughout the development cycle, making it possible to plan more efficient and sustainable managements. In each cultivation system (soybeans/oats; maize/oats), two experiments were carried out in 2017 and 2018, one for analyzing grain yield and the other for cutting every 30 days to obtain biomass. The experiments were conducted in a randomized block design with four replications for four levels of $\mathrm{N}$-fertilizer $\left(0,30,60\right.$ and $\left.120 \mathrm{~kg} \mathrm{ha}^{-1}\right)$, applied in the stage of the 4th expanded leaf. The use of the artificial neural network makes it possible to predict grain yield by harvesting the biomass obtained at any stage of oat development, together with the handling of the nitrogen dose and meteorological information during cultivation. Therefore, a new tool
\end{abstract}


to aid the simulation of oat productivity throughout the cycle, facilitating faster decision making for more efficient and sustainable management with the crop.

Keywords: nitrogen, modeling, biomass, temperature, rainfall, sustainability

\section{Introduction}

The use of artificial neural networks (ANN) has been growing gradually in the representation of the complex system, mainly in a non-linear variable (Leal et al., 2015; Fleck et al., 2016). The ANN are mathematical models based on the biological nervous system, formed by neurons that can be distributed in several interconnected layers, which, through training, store knowledge and generalize the information learned, being able to solve complex problems and model the behavior of the variables involved (Saraceno et al., 2010; Azarpour et al., 2015). In agriculture, neural networks can be used to develop prediction models in complex systems and estimate desired parameters, enhancing process optimization and decision making (Huang, et al., 2010; Silva et al., 2014).

The implementation of new technologies for the management of agricultural crops has received attention from researchers in the search for a healthy diet. Due to the necessity to optimize food production with cost reduction and sustainability to ecosystems (Nikolla et al., 2014; Arenhardt et al. 2017). Furthermore, white oats are being used more in the food industry, as flakes, as it is an extremely nutritious and healthy cereal (Gutkoski et al., 2009; Silva et al., 2015).

Nitrogen as fertilizer is the essential element to assure proper oat grain yield requests from the industry (Marolli et al., 2017a; Scremin et al., 2017), but their management is one of the most complex because there are high losses by lixiviation, volatilization, which increase production costs and environmental damage (Brezolin et al., 2017; Marolli, et al., 2018). Is highlighted weather elements, the rainfall and air temperature, are strictly linked to the nitrogen gain and losses by the plant, also are the most related to oat grain (Simili et al., 2008; Marolli et al., 2017b). These elements are non-linear variables, which difficulties the modeling use to predict yield. However, the study of biological processes, the climate and the management all over the growth cycle by ANN, can represent a new technology to make decisions, adding important information to the biological variables and environment, of linear and non linear behavior. It allows the patterns recognition in the generation of prognosis with reduction in production costs and maximizing profits.

The study aimed to develop biomathematics models by ANN, capable of predicting oat grain yield per weather variable, nitrogen management and biomass, obtained all over the development cycle.

\section{Method}

\subsection{Experimental Design Area}

The field experiment was carried out in 2017 and 2018, in the municipality of Augusto Pestana, Brazil (28 '26 '30' 'latitude S and $54^{\circ} 00^{\prime}$ ' $58^{\prime}$ ' longitude W). The soil of the experimental area was classified as Typical Red Latosol and the climate of the region, according to the Köppen classification, of the Cfa type (humid subtropical), with well-distributed rain during the year and the average temperature of the hottest month above $22^{\circ} \mathrm{C}$. In the study, ten days 
before sowing, soil analysis was carried out and the following chemical characteristics of the site were identified (Tedesco et al., 1995): i) maize/oat system: $\left(\mathrm{pH}=6,5 ; \mathrm{P}=34,4 \mathrm{mg} \mathrm{dm}^{-3} ; \mathrm{K}\right.$ $\left.=262 \mathrm{mg} \mathrm{dm}{ }^{-3} ; \mathrm{MO}=2,9 \% ; \mathrm{Al}=0 \mathrm{cmol}_{c} \mathrm{dm}^{-3} ; \mathrm{Ca}=6,6 \mathrm{cmol}_{\mathrm{cdm}}{ }^{-3} \mathrm{e} \mathrm{Mg}=3,4 \mathrm{cmol}_{c} \mathrm{dm}^{-3}\right)$ and; ii) soybean/oat system: $\left(\mathrm{pH}=6,2 ; \mathrm{P}=33,9 \mathrm{mg} \mathrm{dm}^{-3} ; \mathrm{K}=200 \mathrm{mg} \mathrm{dm}^{-3} ; \mathrm{MO}=3,0 \% ; \mathrm{Al}=0\right.$ $\left.\mathrm{cmol}_{c} \mathrm{dm}^{-3} ; \mathrm{Ca}=6,5 \mathrm{cmol}_{c} \mathrm{dm}^{-3} \mathrm{e} \mathrm{Mg}=2,5 \mathrm{cmol}_{c} \mathrm{dm}^{-3}\right)$. In the two years of experiment, sowing was carried out in the second half of June, according to the cultivation recommendation.

The seeds were sown with a seeder-fertilizer in five 5-m-length lines spaced by $0.20 \mathrm{~m}$, with an experimental area of $5 \mathrm{~m}^{2}$. The population density was 400 seeds $\mathrm{m}^{-2}$ viable seeds, and the cultivar URS-Corona. During the work, applications were made tebuconazole fungicide of the commercial name FOLICUR® CE was applied in the dosage of $0.75 \mathrm{~L} \mathrm{ha}^{-1}$, and of the metsulfuron-methyl herbicide of the commercial name ALY® in the dose of $4 \mathrm{~g} \mathrm{ha}^{-1}$. In the sowing, 45 and $30 \mathrm{~kg} \mathrm{ha}^{-1}$ of $\mathrm{P}_{2} \mathrm{O}_{5}$ and $\mathrm{K}_{2} \mathrm{O}$ were applied based on the contents of $\mathrm{P}$ and $\mathrm{K}$ in the soil in the expectation of grain yield of $3 \mathrm{t} \mathrm{ha}^{-1}$ respectively and $10 \mathrm{~kg} \mathrm{ha}^{-1}$ of nitrogen (except in the unit standard experiment), with the residual to complete the proposal top-dressing dose in the phenological stage of fourth fully expanded leaves.

Two experimental studies was performed in each crop condition (soybean/ oat, maize/ oat systems). One to quantify biomass yield (BY, $\mathrm{kg} \mathrm{ha}^{-1}$ ) through the cutting performed every 30 days until physiological maturity and the other to the grain yield estimative ( $\mathrm{GY}, \mathrm{kg} \mathrm{ha}^{-1}$ ). Therefore, at the four experiments the trial design was in randomized blocks with four replicates for four $\mathrm{N}$-fertilizer doses (urea) in the level $\left(0,30,60\right.$, and $\left.120 \mathrm{~kg} \mathrm{ha}^{-1}\right)$. The grain yield was obtained by cutting the three central lines of each plot at the harvest maturity, then was threshed and the grain moisture corrected to $13 \%$ at the laboratory to the grain yield estimative. To quantify biomass productivity $\left(\mathrm{BY}, \mathrm{kg} \mathrm{ha}^{-1}\right)$ the material plant was harvested close to the soil by collecting a linear meter in the three central lines of each plot in 30,60, 90, and 120 days after emergence, a total of four cuttings.

To estimate biomass productivity the plant material was dried in a forced-air oven at $65^{\circ} \mathrm{C}$ until stabilized weight. The values of maximum air temperature and rainfall, obtained through the Total Automatic Station installed 500 meters from the experimental area.

\subsection{ANN Simulation Model}

The simulation of the oat grain yield for a development stage was mathematics modeling by ANN, using Neural Network Toolbox of Matlab software. These networks are trained using a backpropagation algorithm as activated function of the hidden layer hyperbolic sigmoid tangent, and the training rule Levemberg-Merquadt (LM). The backpropagation is a generalization of the learning algorithm Widrow and Hoff - Least Mean Square (LMS), known as delta rule (Faraco et al., 1998), falls under the category of supervised learning. Network performance is measured by an error function that considers, for each of the different standards $p$ on input, the square of the difference between the expected value and the respective calculated output. In other words, the error is the sum of the quadratic errors, defined by the following expression: 


$$
E=\sum_{i, p} E_{i}^{p}=\frac{1}{2} \sum_{i, p}\left(d_{i}^{p}-O_{i}^{p}\right)^{2}
$$

$E_{i}^{p}$ represents the error of the i-th neural element, for the p-th input,

$d_{i}^{p}$ is the output expected on the $\mathrm{i}$-th neural element, for the $\mathrm{p}$-th input and $O_{i}^{p}$ is the output produced, is the output produced, defined as:

$$
O_{i}^{p}=f\left(a_{i}^{p}\right)=f\left(\sum_{j} w_{i j} v_{j}^{p}-\theta_{i}\right)
$$

$v_{j}^{p}$ is the $j$-th input component $V^{p}$.

The backpropagation algorithm acts on synaptic weights, minimizing the error function, using the descending gradient technique. In this method, the weight values are modified proportionally to the opposite of the error derivative, according to the following expression:

$$
\Delta w_{i j}=\gamma \frac{\partial E_{i}^{p}}{\partial w_{i j}}
$$

$Y$, called the learning rate, it controls how big the "step" must be taken.

Defining $d_{i}^{p, k}$, as output expected in the $i$-th unit of the $k$-th layer, when the $p$-th pattern is presented to the network and,

$$
O_{i}^{p, k}=f\left(a_{i}^{p, k}\right)
$$

as the real output is, $a_{i}^{p, k}=\sum_{j} w_{i j}^{k} O_{j}^{p, k-1}-\theta_{i}$ e $O_{i}^{p, 0}=v_{i}^{p}$, the error function, in the $k$ layer, can be describe:

$$
E^{k}=\frac{1}{2} \sum_{i, p}\left(d_{i}^{p, k}-O_{j}^{p, k}\right)^{2}
$$

The weights correction in the output layer $\mathrm{K}$ is given by applying the chain rule 


$$
\Delta w_{i j}^{K}=-\gamma \frac{\partial E^{K}}{\partial w_{i j}^{K}}=-\gamma \sum_{p} \frac{\partial E^{K}}{\partial O_{i}^{p, K}} \frac{\partial O_{i}^{p, K}}{\partial a_{i}^{p, K}} \frac{\partial a_{i}^{p, K}}{\partial w_{i j}^{K}}=\gamma \sum_{p} \delta_{i}^{p, K} O_{j}^{p, K-1}
$$

defining itself

$$
\delta_{i}^{p, K}=f^{\prime}\left(a_{i}^{p, K}\right)\left(d_{i}^{p, K}-O_{i}^{p, K}\right)
$$

Similarly, it can be shown that in the hidden layers the correction is given by:

$$
\Delta w_{i j}^{K}=-\gamma \frac{\partial E^{K}}{\partial w_{i j}^{K}}=\gamma \sum_{p} \delta_{i}^{p, K} O_{j}^{p, K-1}
$$

defining itself

$$
\delta_{i}^{p, K}=f^{\prime}\left(a_{i}^{p, K}\right) \sum_{j} w_{i j}^{K+1} \delta_{j}^{p, K+1}
$$

The sigmoidal function is the most widely used, as it is a monotonic and easily derived function, with its basic model as:

$$
O_{i}=f\left(a_{i}\right)=\frac{1}{1+e^{-a_{i}}}
$$

$a$ can assume value between 0 and 1 been $i$ the active neuron value. Its derivative is:

$$
f^{\prime}\left(a_{i}\right)=\frac{e^{-a_{i}}}{\left(1+e^{-a_{i}}\right)^{2}}
$$

Levenberg-Marquardt training is a function that updates the bias weights and values according to Levenberg-Marquardt optimization. It is often considered to be the fastest of the error propagation training algorithms, but it requires more computational memory than the other algorithms. In the Levenberg-Marquardt algorithm, the changes $(\Delta)$ in the weights $(\vec{w})$ are are obtained (Lera \& Pinzolas, 2002),

$$
\alpha \Delta=\frac{-1}{2} \nabla E
$$

$E$ is the mean square error of the network, 


$$
E=\frac{1}{N} \sum_{k=1}^{N} \quad\left[\vec{y}\left(x_{k}\right)-\vec{d}_{k k}\right]^{2}
$$

$N$ is the number of examples, $\vec{y}\left(x_{k}\right)$ is the network output corresponding to the example $x_{k}$ and $\vec{d}_{k}$ is the desired output for that example.

The $\alpha$ matrix elements are given by:

$$
\alpha_{i j}=\left(1+\lambda \delta_{i j}\right) \sum_{r=1}^{p} \sum_{k=1}^{N}\left[\frac{\partial y_{r}\left(x_{k}\right)}{\partial w_{i}} \frac{\partial y_{r}\left(x_{k}\right)}{\partial w_{j}}\right]
$$

$\mathrm{p}$ is the number of exits from the network. Starting with the random starting weights, both $\alpha$ and $\nabla E$ are calculated by solving Equation 12. The correction for the weight values is obtained by $\left(\overrightarrow{w^{\prime}}=\vec{w}+\Delta\right)$, known as the Levenberg-Marquardt learning period. Each iteration with these times reduces the error until it finds a minimum. The $\lambda$ variable in Equation 14 is the parameter that is adjusted each season according to the evolution of the error.

In each ANN architecture, the data was divided randomly at $70 \%$ for training (database with 128 samples), $15 \%$ for tests and $15 \%$ for validation. The input variables used in the artificial neural network were: $\mathrm{N}$-fertilizer dose $\left(0,30,60\right.$ e $\left.120 \mathrm{~kg} \mathrm{ha}^{-1}\right)$, the oat development stage after emergence (30, 60, 90 e 120 days), the biomass yield, rainfall load and the medium temperature load in each development stage, the output variable of the neural network was oat grain yield. To ensure that the data received equal attention during the training process, thus increasing its efficiency, both the input and output data of the neural network are standardized for the range of -1 to 1 , by the data normalization process, expressed by the following equation:

$$
p n=\frac{2(p-p)}{p-p}-1
$$

$p n$ is the normalized, dimensionless value; $p$ is the observed value; $p$, is the minimum sample

value; and $p$, the maximum sample value. At the beginning of the training, the free parameters are generated randomly and that these initial values can influence the final result of the training, 10 networks of each architecture were trained. Before the ANN architecture training, were chosen the lowest mean relative error (MRE) regard the validation data, and the lowest mean squared error (MSE) related to the training data. Each network was composed of 3 layers (input, hidden and output), in input layer with 5 neurons, the hidden layer varied between 5 to 25 (adding every 5 neurons) and a output layer with 1 neuron. To represent the ANN architecture were used the signal "NI-NHL-NNO" NI = input variable numbers, NHL = hidden layer 


\section{Ml Macrothink}

neuron numbers and NNO = output layer neuron numbers. For the training and validation of ANNs, were used the experimental data obtained in 2017 and 2018 in the field experiment.

\section{Results and Discussion}

In Figure 1 of the oat cultivation period, it was noticed that the air temperatures were higher in 2017 than in 2018. In addition, in 2017, the rainfall was $813 \mathrm{~mm}$ (Figure 1A) and in 2018 it was $785 \mathrm{~mm}$ (Figure 1B), they were close to the average of the last 20 years $(900 \mathrm{~mm})$, however, with a different distribution between the years. In 2017, the volume of rainfall was low in the vegetative phase, accompanied by a high maximum air temperature. Circumstance that benefits nitrogen losses through volatilization and reduces the stimulus of new tillers, a component directly linked to grain productivity. The most intense rains occurred in the second half of the oat cultivation cycle and extended until close to the harvest in 2017, a condition that indicates less sunstroke and, consequently, reduction in the performance and efficiency of photosynthesis.

In 2018, the largest amount of rainfall was from sowing at 35 days of oat development and with milder maximum air temperature compared to 2017. These conditions favor the maintenance of soil moisture and increase the nitrogen efficiency used by the plant. In addition, from half the cycle to maturation, rainfall volumes were distributed with lesser intensity, improving the oats development conditions, justifying the higher grain productivity obtained in 2018 .
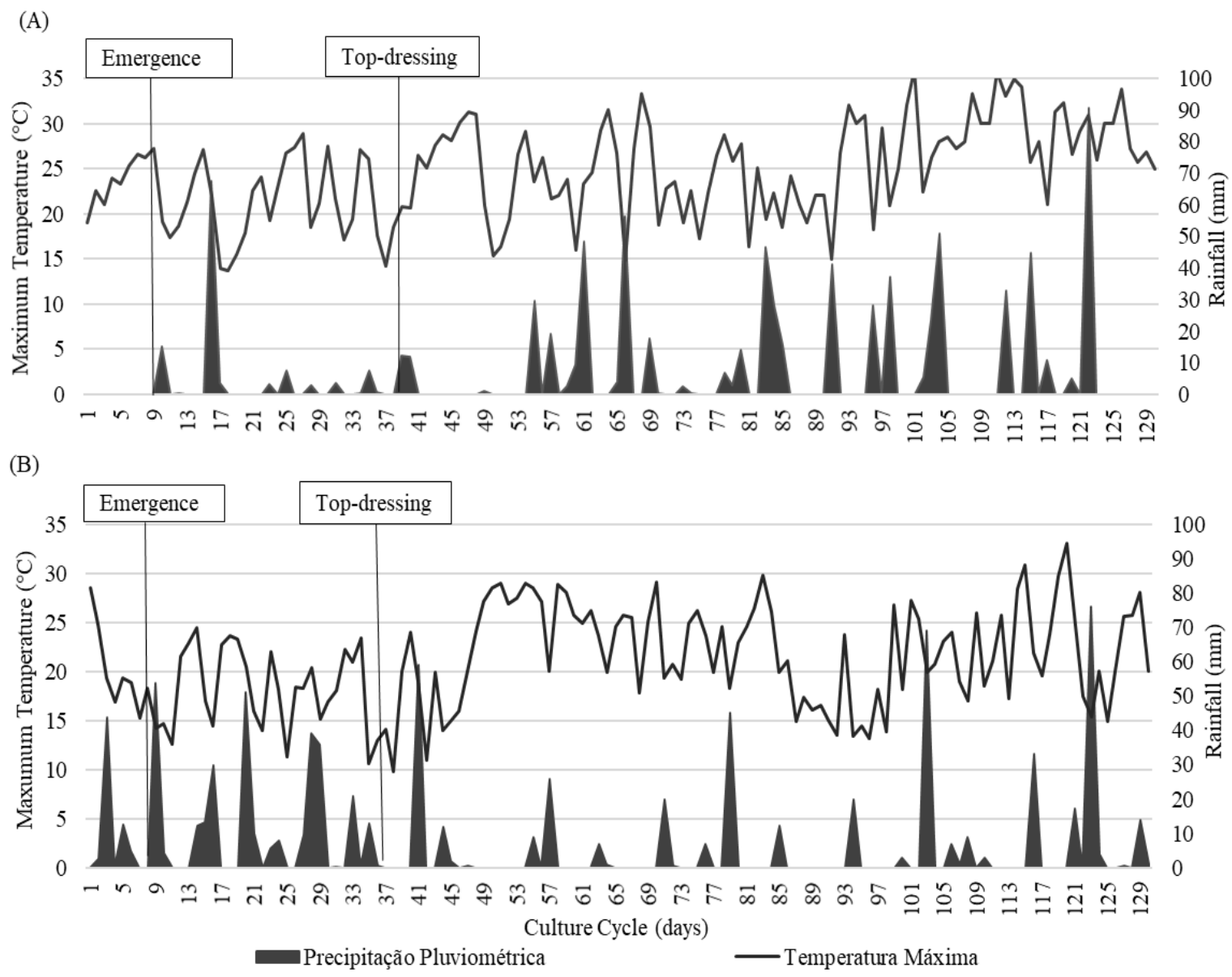

Figure 1. Rainfall and maximum temperature sowing to harvest $(A)=2017,(B)=2018$ 
The location and environment are decisive factors for grain yield, with climatic variations throughout the development cycle is the factor that most contributes to the yield changes (Ferrari Neto et al., 2012; Costa et al., 2016). In wheat and oat the crop year condition is defined by the rainfall amount and air temperature (Arenhardt et al., 2015; Marolli et al., 2017a). These affect the rate of organic matter decomposition in contact with the soil and affect the efficiency of nitrogen use by the plant (Acosta et al., 2014). Air temperature is also a determining factor in the yield development, since it acts as a catalyst for biological processes, which is why plants require a minimum and maximum temperature for normal physiological activities (Guarienti et al., 2004; Tonin et al., 2014a; Tonim et al., 2014b). Arenhardt et al. (2015), highlight that longs rainfall season reduce the efficiency of harnessing sunlight and nutrients to photosynthesis, interfering in the development, productivity and quality of grains during harvest (Castro, 2012; Mamann et al., 2017). For oats, the favorable climate is described as milder temperatures with radiation quality, it favors tillering and grain filling, without the occurrence of rainfall in large quantities and intensity. However, it favors an adequate supply of moisture stored in the soil (Castro et al., 2012; Marolli et al., 2017b).

Table 1 shows the mean square error in the training process and the mean relative error and variance, verified in the development of the artificial neural network. In the soybean/oat system the network architecture of 5-5-1 to 5-20-1 showed closest value of mean relative error next, but when variance is observed in the validation process, the architecture 5-5-1 showed minor value from the other. It represents that the error for all the data training decreased, but there will not necessarily be a reduction on the validation values. However, since it exhibits low value of variance, it does not express low mean relative error for the validation data (Table 1), in addition to presenting the relationship between the number of training samples and the number of hidden connections greater than 2, as indicated by Masters (1993). Besides, must be careful that networks with many neurons on the hidden layer can memorize training padrons instead of extracting generalizing characteristics (produce suitable outputs to inputs that were not present in the training (Braga et al., 2000; Teodoro et al., 2015). Thus, following the interpretation proposed by Masters (1993) and Braga et al., (2000), for this crop system the network architecture of 5-10-1, because it showed better capacity to predict oat grain yield.

Table 1. Mean quadratic error value, for all the training, mean relative error and variance for the data validation, in the training architecture

\begin{tabular}{cccc}
\hline $\begin{array}{c}\text { Architecture } \\
\text { NI- }>\text { NH- }>\text { NO }\end{array}$ & $\begin{array}{c}\text { Mean quadratic error } \\
\text { (training) }\end{array}$ & mean relative error (validation) & Variance (validation) \\
\hline $5-5-1$ & $5.54 \mathrm{E}-3$ & soybean/oat system & $1.01 \mathrm{E}-2$ \\
$5-10-1$ & $5.51 \mathrm{E}-3$ & $7.76 \mathrm{E}-3$ & $7.82 \mathrm{E}-3$ \\
$5-15-1$ & $5.83 \mathrm{E}-3$ & $6.29 \mathrm{E}-3$ & $1.42 \mathrm{E}-2$ \\
$5-20-1$ & $5.64 \mathrm{E}-3$ & $7.85 \mathrm{E}-3$ & $2.32 \mathrm{E}-2$ \\
$5-25-1$ & $6.81 \mathrm{E}-3$ & $1.44 \mathrm{E}-2$ & $2.32 \mathrm{E}-2$ \\
$5-5-1$ & & & $1.96 \mathrm{E}-2$ \\
\hline $5-10-1$ & $6.31 \mathrm{E}-3$ & maize/oat system & $7.77 \mathrm{E}-3$ \\
$5-15-1$ & $6.75 \mathrm{E}-3$ & $4.77 \mathrm{E}-3$ & $6.37 \mathrm{E}-3$ \\
$5-20-1$ & $5.89 \mathrm{E}-3$ & $5.69 \mathrm{E}-3$ & $7.78 \mathrm{E}-3$ \\
$5-25-1$ & $6.39 \mathrm{E}-3$ & $1.78 \mathrm{E}-2$ & $8.32 \mathrm{E}-3$ \\
\hline
\end{tabular}




\section{Macrothink}

Journal of Agricultural Studies

ISSN 2166-0379

2020, Vol. 8, No. 4

$\mathrm{NI}=$ Number of input layer neurons; $\mathrm{NH}=$ Number of hidden layer neurons; $\mathrm{NO}=$ number of output layer neurons

In the maize/oat system (Table 1), the minor mean quadratic error was observed in the 5-25-1 architecture, but, with more validation variation. Then, following the precept on choosing the soybean/oat system, was selected to maize/oat system the 5-15-1 structure, to represent lower mean quadratic error than the other structure and to have lower mean relative error.

The results found in the 10 and 15 neurons configuration in the hidden layer showed there is not the need for complex structures, because the hidden layer does not represent linearity between the data (Soares et al., 2015; Dornelles et al., 2018) and, in this case, there is not more complexity on the structure to understand yield tendency by climate condition, and the biomass manager in oat. Braga et al. (2007) and Bullinaria, (2016) indicated simpler configuration to apply ANN, avoiding overfitting occurrence and making the research process and configuration optimization easier to a certain task.

In Figure 2, the determination coefficients of training (70\% data), validation (15\% data), test (15\% data) and total network (100\% data) of the soybean/oat and maize/oat system. The determination coefficients of the chosen networks demonstrate the reliability and confirm that the generated algorithm scales the behavior of the actual data obtained, effectively, presenting values close to 1 , that is, $100 \%$.

(A)
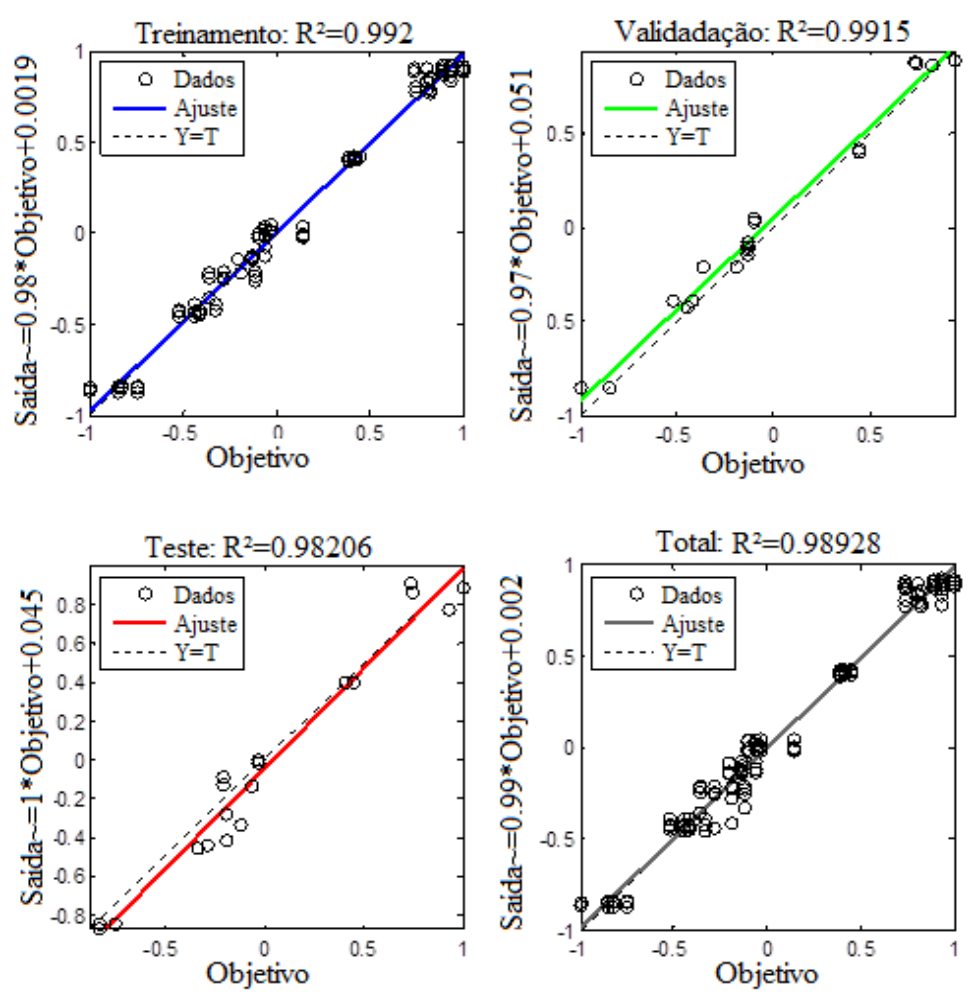
(B)
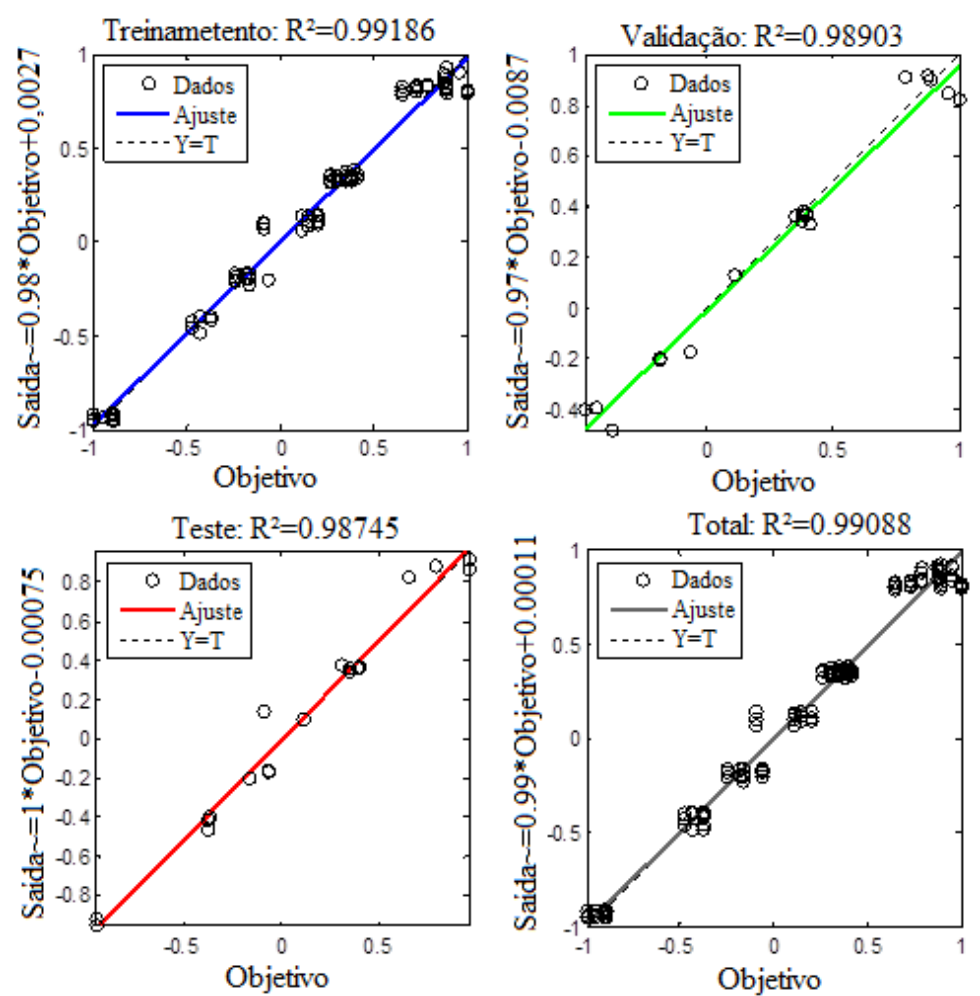

Figure 2. training coefficient determination, test, validation and all (training, test, validation) Of the ANN. (A)= Architecture 5-10-1 to soybean/oat system; $(B)=$ Architecture 5-15-1 to soybean/maize system

To verify the performance of the ANN chosen for each crop system, in the 2 and 3 Table, the architecture 5-10-1 and 5-15-1 of the soybean/oat and maize/oat system, were compared the grain yield value obtain by the cumulative effect of the years $2017+2018$ with the estimated value of ANN. To the input values of the artificial neural network were used the doses of $\mathrm{N}$-fertilizer, the oat development stages, the biological yield, the accumulated rainfall mean and the maximum temperature mean accumulated in each stage of oat development (Figure 2). 
Table 2. Values comparison of the grain oat yield obtained in the validation of ANN with architecture 5-10-1 and in the field experiment in the soybean / oat system

\begin{tabular}{|c|c|c|c|c|c|c|c|}
\hline \multirow{2}{*}{$\mathrm{N}$} & \multirow{2}{*}{$\begin{array}{l}\text { Cycle } \\
\text { (days) }\end{array}$} & \multirow{2}{*}{ Year } & \multirow{2}{*}{$\begin{array}{c}\mathrm{YB} \\
\left(\mathrm{kg} \mathrm{ha}^{-1}\right)\end{array}$} & \multirow{2}{*}{$\sum_{(\mathrm{mm})}$} & \multirow{2}{*}{$\begin{array}{l}T_{\text {max }} \\
\left({ }^{\circ} \mathrm{C}\right)\end{array}$} & \multicolumn{2}{|c|}{ GY $\left(\mathrm{kg} \mathrm{ha}^{-1}\right)(2017+2018)$} \\
\hline & & & & & & Simulation/ANN & trust interval \\
\hline \multirow{8}{*}{0} & \multirow{2}{*}{30} & 2015 & 288 & 337 & 18.4 & \multirow{2}{*}{2322} & \multirow[t]{2}{*}{$\mathrm{L}_{\mathrm{i}}=1987$} \\
\hline & & 2014 & 345 & 112 & 21.3 & & \\
\hline & \multirow{2}{*}{60} & 2015 & 1317 & 480 & 20.0 & \multirow{2}{*}{2260} & \multirow[t]{2}{*}{$\bar{X}=2220$} \\
\hline & & 2014 & 1430 & 307 & 23.0 & & \\
\hline & \multirow{2}{*}{90} & 2015 & 4117 & 565 & 20.2 & \multirow{2}{*}{2320} & \multirow[t]{4}{*}{$\mathrm{L}_{\mathrm{s}}=2420$} \\
\hline & & 2014 & 4594 & 548 & 23.1 & & \\
\hline & \multirow{2}{*}{120} & 2015 & 9919 & 785 & 20.7 & \multirow{2}{*}{2215} & \\
\hline & & 2014 & 5044 & 813 & 24.7 & & \\
\hline \multirow{8}{*}{30} & \multirow{2}{*}{30} & 2015 & 327 & 337 & 18.4 & \multirow{2}{*}{3179} & \multirow[t]{2}{*}{$\mathrm{L}_{\mathrm{i}}=2750$} \\
\hline & & 2014 & 370 & 112 & 21.3 & & \\
\hline & \multirow{2}{*}{60} & 2015 & 2188 & 480 & 20.0 & \multirow{2}{*}{3188} & \multirow[t]{2}{*}{$\bar{X}=3035$} \\
\hline & & 2014 & 1722 & 307 & 23.0 & & \\
\hline & \multirow{2}{*}{90} & 2015 & 5059 & 565 & 20.2 & \multirow{2}{*}{3183} & $\mathrm{~L}_{\mathrm{s}}=3278$ \\
\hline & & 2014 & 8266 & 548 & 23.1 & & \\
\hline & 120 & 2015 & 11972 & 785 & 20.7 & 3059 & \\
\hline & $1 \angle 0$ & 2014 & 8857 & 813 & 24.7 & 3059 & \\
\hline & 30 & 2015 & 320 & 337 & 18.4 & 3444 & $\mathrm{~L}_{\mathrm{i}}=2872$ \\
\hline & 50 & 2014 & 359 & 112 & 21.3 & 3444 & \\
\hline & 60 & 2015 & 2250 & 480 & 20.0 & 3481 & $\bar{X}=3342$ \\
\hline 60 & 00 & 2014 & 3131 & 307 & 23.0 & 3481 & \\
\hline 00 & & 2015 & 8611 & 565 & 20.2 & & $\mathrm{~L}_{\mathrm{s}}=3745$ \\
\hline & 90 & 2014 & 9681 & 548 & 23.1 & 3485 & \\
\hline & & 2015 & 12051 & 785 & 20.7 & & \\
\hline & 120 & 2014 & 11012 & 813 & 24.7 & 3452 & \\
\hline & 30 & 2015 & 304 & 337 & 18.4 & 3171 & $\mathrm{~L}_{\mathrm{i}}=3061$ \\
\hline & 30 & 2014 & 369 & 112 & 21.3 & $31 / 1$ & \\
\hline & 60 & 2015 & 3234 & 480 & 20.0 & 3244 & $\bar{X}=3192$ \\
\hline 120 & 00 & 2014 & 3398 & 307 & 23.0 & 3244 & \\
\hline 120 & 90 & 2015 & 9531 & 565 & 20.2 & 3161 & $L_{s}=3663$ \\
\hline & 90 & 2014 & 11295 & 548 & 23.1 & 3101 & \\
\hline & 120 & 2015 & 14864 & 785 & 20.7 & 3159 & \\
\hline & 120 & 2014 & 11939 & 813 & 24.7 & צנכנד & \\
\hline
\end{tabular}

$\sum_{\text {rain }}=$ rainfall summation; $\bar{T}_{\max }=$ maximum mean temperature; $\mathrm{N}=\mathrm{N}$-fertilizer $\left(\mathrm{kg} \mathrm{ha}{ }^{-1}\right)$;

$\mathrm{BY}=$ biological yield; $\mathrm{GY}=$ grain yield; $\mathrm{ANN}=$ Artificial neural network; $\mathrm{L}_{\mathrm{i}}=$ inferior limit; $\bar{X}=$ mean; $\mathrm{L}_{\mathrm{s}}=$ superior limit

In Table 2, soybean/oat system, the simulation showed high capacity to predict for oat grain yield, the values simulated by the ANN were between the truste interval of cumulative effects in the year 2017 and 2018. In the maize oat system (Table 3), the simulation also stayed between the truste interval. The ability to understand exemples and generalize information is the main problem solution by ANN, (Wasserman, 1989; Martins et al., 2016). The generalization that is associated with the network's ability to learn from a small set of examples and subsequently provide coherent responses to unknown data is a demonstration that a ANN go beyond simply mapping input and output relationships (Soares et al., 2014). These results show that the use of the network enables the predictability of grain yield at any OAT 
development stage, in any condition of use of the $\mathrm{N}$-fertilizer and in different succession systems, becoming a tool to aid decision making regarding the management of culture.

One thing to regard is that the Neural Network can accept different input data. Thus, data collected in the field, such as topographic conditions and measures, edaphic parameters, phytomass values, stage of development of agricultural crops, etc., can also be used as a source of definition and context for a specific target, important in the task of memorization thematic feature (Bucene \& Rodrigues, 2004; Depiné et al., 2014; Dornelles et al., 2018).

Table 3. Values comparison of the grain oat yield obtained in the validation of ANN with architecture 5-15-1 and in the field experiment in the maize / oat system

\begin{tabular}{|c|c|c|c|c|c|c|c|}
\hline \multirow{2}{*}{$\mathrm{N}$} & \multirow{2}{*}{$\begin{array}{l}\text { Stage } \\
\text { (days) }\end{array}$} & \multirow{2}{*}{ Year } & \multirow{2}{*}{$\begin{array}{c}\text { BY } \\
\left(\mathrm{kg} \mathrm{ha}^{-1}\right)\end{array}$} & \multirow{2}{*}{$\sum_{(\mathrm{mm})}$} & \multirow{2}{*}{$\begin{array}{l}T_{\text {max }} \\
\left({ }^{\circ} \mathrm{C}\right)\end{array}$} & \multicolumn{2}{|c|}{ GY $\left(\mathrm{kg} \mathrm{ha}^{-1}\right)(2017+2018)$} \\
\hline & & & & & & Simulation/ANN & Trust interval \\
\hline \multirow{8}{*}{0} & \multirow{2}{*}{30} & 2015 & 324 & 337 & 18.4 & \multirow{2}{*}{1458} & \multirow[t]{2}{*}{$\mathrm{L}_{\mathrm{i}}=1240$} \\
\hline & & 2014 & 195 & 112 & 21.3 & & \\
\hline & \multirow{2}{*}{60} & 2015 & 854 & 480 & 20.0 & \multirow{2}{*}{1524} & \multirow[t]{2}{*}{$\bar{X}=1551$} \\
\hline & & 2014 & 1029 & 307 & 23.0 & & \\
\hline & \multirow{2}{*}{90} & 2015 & 4370 & 565 & 20.2 & \multirow{2}{*}{1522} & \multirow[t]{4}{*}{$\mathrm{L}_{\mathrm{s}}=1818$} \\
\hline & & 2014 & 4462 & 548 & 23.1 & & \\
\hline & \multirow{2}{*}{120} & 2015 & 7524 & 785 & 20.7 & \multirow{2}{*}{1517} & \\
\hline & & 2014 & 4657 & 813 & 24.7 & & \\
\hline \multirow{8}{*}{30} & \multirow{2}{*}{30} & 2015 & 326 & 337 & 18.4 & \multirow{2}{*}{2384} & \multirow[t]{2}{*}{$\mathrm{L}_{\mathrm{i}}=2163$} \\
\hline & & 2014 & 230 & 112 & 21.3 & & \\
\hline & \multirow{2}{*}{60} & 2015 & 1484 & 480 & 20.0 & \multirow{2}{*}{2430} & \multirow[t]{2}{*}{$\bar{X}=2476$} \\
\hline & & 2014 & 1305 & 307 & 23.0 & & \\
\hline & \multirow{2}{*}{90} & 2015 & 4991 & 565 & 20.2 & \multirow{2}{*}{2431} & $\mathrm{~L}_{\mathrm{s}}=2745$ \\
\hline & & 2014 & 6564 & 548 & 23.1 & & \\
\hline & 120 & 2015 & 9515 & 785 & 20.7 & 2584 & \\
\hline & 120 & 2014 & 8490 & 813 & 24.7 & 2584 & \\
\hline & 30 & 2015 & 294 & 337 & 18.4 & 2840 & $\mathrm{~L}_{\mathrm{i}}=2451$ \\
\hline & 30 & 2014 & 268 & 112 & 21.3 & 2840 & \\
\hline & 60 & 2015 & 1857 & 480 & 20.0 & 2807 & $\bar{X}=2902$ \\
\hline 60 & 60 & 2014 & 1968 & 307 & 23.0 & 2891 & \\
\hline 00 & 90 & 2015 & 5587 & 565 & 20.2 & 2852 & $\mathrm{~L}_{\mathrm{s}}=3289$ \\
\hline & 90 & 2014 & 7845 & 548 & 23.1 & 2852 & \\
\hline & 120 & 2015 & 10628 & 785 & 20.7 & 3030 & \\
\hline & 120 & 2014 & 10282 & 813 & 24.7 & 3050 & \\
\hline & 30 & 2015 & 272 & 337 & 18.4 & & $\mathrm{~L}_{\mathrm{i}}=2778$ \\
\hline & 30 & 2014 & 300 & 112 & 21.3 & 3032 & \\
\hline & 60 & 2015 & 2668 & 480 & 20.0 & 2126 & $\bar{X}=3094$ \\
\hline 120 & 00 & 2014 & 2685 & 307 & 23.0 & 3126 & \\
\hline 120 & 00 & 2015 & 6353 & 565 & 20.2 & 2007 & $\mathrm{~L}_{\mathrm{s}}=3364$ \\
\hline & 90 & 2014 & 9803 & 548 & 23.1 & 2991 & \\
\hline & 120 & 2015 & 12111 & 785 & 20.7 & 3181 & \\
\hline & 120 & 2014 & 11179 & 813 & 24.7 & 5101 & \\
\hline
\end{tabular}

$\sum_{\text {rain }}=$ rainfall summation; $\bar{T}_{\max }=$ maximum mean temperature; $\mathrm{N}=\mathrm{N}$-fertilizer $\left(\mathrm{kg} \mathrm{ha}^{-1}\right)$; $\mathrm{BY}=$ biological yield; $\mathrm{GY}=$ grain yield; $\mathrm{ANN}=$ Artificial neural network; $\mathrm{L}_{\mathrm{i}}=$ inferior limit; $\bar{X}=$ mean $\mathrm{L}_{\mathrm{s}}=$ superior limit

Despite the promising results of using a neural network system to predict oat yield throughout the development stages, there is a need to qualify this technique for future data analysis, with a 
greater number of predictor variables, both for the plant and the ground. Therefore, it is suggested to test different configurations of neural networks, in order to obtain a greater relationship between productivity data, soil attributes, plant attributes, management and climate, thus obtaining greater accuracy in the estimates of variables of interest in crops.

\section{Conclusion}

The use of the artificial neural network makes it possible to predict grain yield by harvesting the biomass obtained at any stage of oat development, together with the handling of the nitrogen dose and meteorological information during cultivation. Therefore, a new tool to aid the simulation of oat productivity throughout the cycle, facilitating faster decision making for more efficient and sustainable management with the crop.

\section{Acknowledgments}

To the Coordination for the Improvement of Higher Education Personnel, National Council for Scientific and Technological Development, Rio Grande do Sul Research Support Foundation and the Regional University of the Northwest of Rio Grande do Sul, to Federal Institute of Education, Science and Technology of Rio Grande do Sul for the financial support to the research and for the Scientific and Technological Initiation Scholarship, Postgraduate Scholarship and Research Productivity Grant.

\section{References}

Acosta, J. A. D. A., Amado, T. J. C., Silva, L. S. D., Santi, A., \& Weber, M. A. (2014). Decomposição da fitomassa de plantas de cobertura e liberação de nitrogênio em função da quantidade de resíduos aportada ao solo sob sistema plantio direto. Ciência Rural, 44(5), 801-809. https://doi.org/10.1590/S0103-84782014005000002

Arenhardt, E. G., da Silva, J. A. G., Gewehr, E., de Oliveira, A. C., Binelo, M. O., Valdiero, A. C., Gzergorczick, M. E., \& de Lima, A. R. C. (2015). The nitrogen supply in wheat cultivation dependent on weather conditions and succession system in southern Brazil. African Journal of Agricultural Research, 10(48), 4322-4330. https://doi.org/10.5897/AJAR2015.10038

Arenhardt, E. G., Silva, J. A. G., Arenhardt, L. G., Carbonari, H. P., Oliveira, A. C. (2017). The nitrogen in grain yield and at lodging oat cultivars. International Journal of Current Research, 9, 45564-45571.

Azarpour, A., Alwi, S. R. W., Zahedi, G., Madooli, M., \& Millar, G. J. (2015). Catalytic activity evaluation of industrial $\mathrm{Pd} / \mathrm{C}$ catalyst via gray-box dynamic modeling and simulation of hydropurification reactor. Applied Catalysis A: General, 489, 262-271. https://doi.org/10.1016/j.apcata.2014.10.048

Braga, A. DE P.; Ferreira, A. DE L.; Ludermir, T. Redes neurais artificiais: teoria e aplicações. 2007.

Braga, A.; Carvalho, A.; Ludermir, T. Redes neurais artificiais: teoria e aplicações. 2000. 
Brezolin, A. P., da Silva, J. A. G., Roos-Frantz, F., Binelo, M. O., Kruger, C. A. M. B., Arenhardt, E. G., ... Dornelles, E. F. (2017). Wheat yield obtained from nitrogen dose and fractionation. African Journal of Agricultural Research, 12(8), 566-576. https://doi.org/10.5897/AJAR2016.11929

Bucene, L. C., \& Rodrigues, L. H. (2004). Utilização de redes neurais artificiais para avaliação de produtividade do solo, visando classificação de terras para irrigação. Revista Brasileira de Engenharia Agrícola e Ambiental, 8(2-3), 326-329. https://doi.org/10.1590/S1415-43662004000200025

Bullinaria, J. A. (2016). Introduction to neural computation. Disponível em: <http://www.cs.bham.ac.uk/ jxb/inc.html>. Acesso em: 22 maio de 2017.

Castro, G. S. A., da Costa, C. H. M., \& Neto, J. F. (2012). Ecofisiologia da aveia branca. Scientia Agraria Paranaensis, 11(3), 1-15. https://doi.org/10.18188/1983-1471/sap.v11n3p1-15

Costa, C. H. M. D., Crusciol, C. A. C., Soratto, R. P., Ferrari Neto, J., \& Moro, E. (2016). Nitrogen fertilization on palisadegrass: phytomass decomposition and nutrients release. Pesquisa Agropecuária $\quad$ Tropical, 46(2), $159-168$. https://doi.org/10.1590/1983-40632016v4639297

Depiné, H., Castro, N. D. R., Pinheiro, A., \& Pedrollo, O. (2014). Preenchimento de falhas de dados horários de precipitação utilizando redes neurais artificiais. Revista Brasileira de Recursos Hídricos, 19(1), 51-63. https://doi.org/10.21168/rbrh.v19n1.p51-63

Dornelles, E. F., Kraisig, A. R., Da Silva, J. A., Sawicki, S., Roos-Frantz, F., \& Carbonera, R. (2018). Artificial intelligence in seeding density optimization and yield simulation for oat. Revista Brasileira de Engenharia Agrícola e Ambiental,22(3), 183-188. https://doi.org/10.1590/1807-1929/agriambi.v22n3p183-188

Faraco, R. A. L., Costa Jr, P. P., \& Cruz, F. R. B. (1998). Minimização do erro no algoritmo back-propagation aplicado ao problema de manutenção de motores. Pesquisa Operacional, 18(1), 22-36.

Ferrari Neto, J., Crusciol, C. A. C., Soratto, R. P., \& Costa, C. H. M. D. (2012). Consórcio de guandu-anão com milheto: persistência e liberação de macronutrientes e silício da fitomassa. Bragantia, 71(2), 264-272. https://doi.org/10.1590/S0006-87052012005000017

Fleck, L., Tavares, M. H., Eyng, E., Helmann, A. C., \& Andrade, M. A. (2016). Redes Neurais Artificiais: Princípios Básicos. Revista Eletrônica Científica Inovação $e$ Tecnologia, 1(13), 47-57. 
Guarienti, E. M., Ciacco, C. F., Cunha, G. R. D., Del Duca, L. D. J. A., \& Camargo, C. M. D. O. (2004). Influência das temperaturas mínima e máxima em características de qualidade industrial e em rendimentos de grãos de trigo. Food Science and Technology, 24(4), 505-515. https://doi.org/10.1590/S0101-20612004000400005

Gutkoski, L. C., Teixeira, D. M. D. F., Durigon, A., Ganzer, A. G., Bertolin, T. E., \& Colla, L. M. (2009). Influência dos teores de aveia e de gordura nas características tecnológicas e funcionais de bolos. Food Science and Technology, 29(2), 254-261. https://doi.org/10.1590/S0101-20612009000200003

Huang, Y., Lan, Y., Thomson, S. J., Fang, A., Hoffmann, W. C., \& Lacey, R. E. (2010). Development of soft computing and applications in agricultural and biological engineering. Computers and electronics in agriculture, 71(2), 107-127. https://doi.org/10.1016/j.compag.2010.01.001

Leal, A. J. F., Miguel, E. P., Baio, F. H. R., Neves, D. D. C., \& Leal, U. A. S. (2015). Redes neurais artificiais na predição da produtividade de milho e definição de sítios de manejo diferenciado por meio de atributos do solo. Bragantia, 74(4), 436-444. https://doi.org/10.1590/1678-4499.0140

Lera, G., \& Pinzolas, M. (2002). Neighborhood based Levenberg-Marquardt algorithm for neural network training. IEEE Transactions on Neural Networks, 13(5), 1200-1203. https://doi.org/10.1109/tnn.2002.1031951

Mamann, Â. T., da Silva, J. A., Scremin, O. B., Mantai, R. D., Scremin, A. H., \& Dornelles, E. F. (2017). Nitrogen efficiency in wheat yield through the biopolymer hydrogel. Revista Brasileira de Engenharia Agrícola e Ambiental,21(10), 697-702. https://doi.org/10.1590/1807-1929/agriambi.v21n10p697-702

Marolli, A., da Silva, J. A. G., Sawicki, S., Binelo, M. O., Scremin, A. H., Reginatto, D. C., ... Lambrecht, D. M. (2018). A simulação da biomassa de aveia por elementos climáticos, nitrogênio e regulador de crescimento. Arquivo Brasileiro de Medicina Veterinária e Zootecnia, 70(2), 535-544. https://doi.org/10.1590/1807-1929/agriambi.v21n3p163-168

Marolli, A., Silva, J. A. G., Romitti, M. V., Mantai, R. D., Hawerroth, M. C., \& Scremin, O. B. (2017a). Biomass and grain yield of oats by growth regulator. Revista Brasileira de Engenharia Agrícola e Ambiental, 21(3), 163-168.

Marolli, A., Silva, J. A. G., Romitti, M. V., Mantai, R. D., Scremin, O. B., Frantz, R. Z., ... de Lima, A. R. C. (2017b). Contributive effect of growth regulator Trinexapac-Ethyl to oats yield in Brazil. African Journal of Agricultural Research, 12(10), 795-804. https://doi.org/10.5897/AJAR2016.11784

Martins, E. R., Binoti, M. L. M. S., Leite, H. G., Binoti, D. H. B., \& Dutra, G. C. (2016). Configuração de redes neurais artificiais para estimação do afilamento do fuste de árvores de eucalipto. Revista Brasileira de Ciências Agrárias, 11(1), 33-38. https://doi.org/10.5039/agraria.v11i1a5354 
Masters, T. Practical neural network recipes in $C++$. San Diego: Academic, p. 493, 1993. https://doi.org/10.1016/B978-0-08-051433-8.50017-3

Nikolla, M., Sena, L., Kolaneci, V., Dib, J. B., \& Sokoli, O. (2014). Analyzing the efficiency of agricultural crop production by using mathematical models. Albanian Journal of Agricultural Sciences, 61.

Saraceno, A., Curcio, S., Calabrò, V., \& Iorio, G. (2010). A hybrid neural approach to model batch fermentation of "ricotta cheese whey" to ethanol. Computers \& Chemical Engineering, 34(10), 1590-1596. https://doi.org/10.1016/j.compchemeng.2009.11.010

Scremin, O. B., Silva, J. A. G., de Mamann, Â. T., Mantai, R. D., Brezolin, A. P., \& Marolli, A. (2017). Nitrogen efficiency in oat yield through the biopolymer hydrogel. Revista Brasileira de Engenharia Agrícola e Ambiental, 21(6), 379-385. https://doi.org/10.1590/1807-1929/agriambi.v21n6p379-385

Silva, A. A., Silva, I. A., Teixeira Filho, M., Buzetti, S., \& Teixeira, M. (2014). Estimativa da produtividade de trigo em função da adubação nitrogenada utilizando modelagem neuro fuzzy. Revista Brasileira de Engenharia Agrícola e Ambiental, 18(2), 180-187. https://doi.org/10.1590/S1415 -4366201 4000200008

Silva, J. A. G., Wohlenberg, M. D., Arenhardt, E. G., de Oliveira, A. C., Mazurkievicz, G., Müller, M., ... Pretto, R. (2015). Adaptability and stability of yield and industrial grain quality with and without fungicide in Brazilian oat cultivars. American Journal of Plant Sciences, 6(09), 1560. https://doi.org/10.4236/ajps.2015.69155

Simili, F. F., Reis, R. A., Furlan, B. N., Paz, C. C. P. D., Lima, M. L. P., \& Bellingieri, P. A. (2008). Resposta do híbrido de sorgo-sudão à adubação nitrogenada e potássica: composição química e digestibilidade in vitro da matéria orgânica. Ciência e Agrotecnologia, 474-480. https://doi.org/10.1590/S1413-70542008000200020

Soares, F. C., Robaina, A. D., Peiter, M. X., \& Russi, J. L. (2015). Predição da produtividade da cultura do milho utilizando rede neural artificial. Ciência Rural, 45(11), 1987-1993. https://doi.org/10.1590/0103-8478cr20141524

Soares, F. C., Robaina, A. D., Peiter, M. X., Russi, J. L., \& Vivan, G. A. (2014). Redes neurais artificiais na estimativa da retenção de água do solo. Ciência Rural,44(2), 293-300. https://doi.org/10.1590/S0103-84782014000200016

Tedesco, M. J., Gianello, C., Bissani, C. A., Bohnen, H., \& Volkweiss, S. J. (1995). Analysis of soils, plants and other materials. ( $2^{\mathrm{a}}$ ed.) Porto Alegre: Federal University of Rio Grande do Sul, 174p.

Teodoro, P. E., Barroso, L. M. A., Nascimento, M., Torres, F. E., Sagrilo, E., dos Santos, A., \& Ribeiro, L. P. (2015). Artificial neural networks to identify semi-prostrate cowpea genotypes with high phenotypic adaptability and stability. Brazilian Agricultural Research, 50(11), 1054-1060. https://doi.org/10.1590/S0100-204X2015001100008 


\section{Macrothink}

Journal of Agricultural Studies

ISSN 2166-0379 2020, Vol. 8, No. 4

Tonin, R. B., Ranzi, C., Camera, J. N., Forcelini, C. A., Reis, E. M. (2014a). Amplitude térmica para germinação de conídios de Drechslera tritici-repentis. Summa Phytopathologica, 40(2), 174-177. https://doi.org/10.1590/0100-5405/1881

Tonin, R. F. B., Lucca Filho, O. A., Labbe, L. M. B., \& Rossetto, M. (2014b). Potencial fisiológico de sementes de milho híbrido tratadas com inseticidas e armazenadas em duas $\begin{array}{llll}\text { condições de } \quad \text { ambiente. Scientia } & \text { Agropecuaria, 5(1), }\end{array}$ https://doi.org/10.17268/sci.agropecu.2014.01.01

Wasserman, P. D. (1989). Neural computing: theory and pratice. New York: Van Nostrand Reinhold.

\section{Copyright Disclaimer}

Copyright for this article is retained by the author(s), with first publication rights granted to the journal.

This is an open-access article distributed under the terms and conditions of the Creative Commons Attribution license (http://creativecommons.org/licenses/by/4.0/). 